\title{
Guava Fruit Fly, Anastrepha striata Schiner (Insecta: Diptera: Tephritidae) ${ }^{1}$
}

\author{
H. V. Weems, Jr. and T. R. Fasulo²
}

\section{Introduction}

Anastrepha striata Schiner is one of the most common species of fruit flies throughout most of its range. It, however, has not acquired a well established common name as have others such as the Mexican, Caribbean, and Mediterranean fruit fly. This probably is because it is not considered to be of primary economic importance, although it often is abundant and may be highly destructive to dooryard plantings of some tropical fruits.

However, Anastrepha striata is an important pest in the American tropics and subtropics, especially of guavas and other myrtaceous fruits, although it has also been reported to attack mango, mombins, orange, and peach. It is considered a pest of quarantine significance by USDA-APHIS-PPQ and many other regulatory agencies. The main damage is caused by the larvae, which feed inside the fruit (Norrbum 2001).

\section{Synonymy}

Dictya cancellaria Fabricius 1805

(From Norrbum 2001)

\section{Distribution}

Mexico (north to southern Sinaloa, Aguascalientes and northern Veracruz) south to Bolivia and Brazil. A few specimens have been collected in the United States (southern Texas and California), but $A$. striata is not currently established there. (Norrbum 2001).

This fruit fly ranges from southern Texas, Mexico, Central America, South to Peru, Bolivia and Brazil. In the West Indies is it found in Trinidad (White and Elson-Harris 1994).

1. This document is EENY-265 (originally published as DPI Entomology Circular 245), one of a series of Featured Creatures from the Entomology and Nematology Department, Florida Cooperative Extension Service, Institute of Food and Agricultural Sciences, University of Florida. Published: January 2002. This document is also available on Featured Creatures Website at http://creatures.ifas.ufl.edu. Please visit the EDIS Website at http://edis.ifas.ufl.edu. Additional information on these organisms, including many color photographs, is available at the Entomology and Nematology Department website at http://entnemdept.ifas.ufl.edu/.

2. H. V. Weems, Jr., Florida Department of Agriculture and Consumer Services, Division of Plant Industry; and T.R. Fasulo, Entomology and Nematology Department, Institute of Food and Agricultural Sciences, University of Florida, Gainesville, FL.

The Institute of Food and Agricultural Sciences (IFAS) is an Equal Employment Opportunity - Affirmative Action Employer authorized to provide research, educational information and other services only to individuals and institutions that function without regard to race, creed, color, religion, age, disability, sex, sexual orientation, marital status, national origin, political opinions or affiliations. For information on obtaining other extension publications, contact your county Cooperative Extension Service office. Florida Cooperative Extension Service / Institute of Food and Agricultural Sciences / University of Florida / Larry R. Arrington, Interim Dean 


\section{Identification}

\section{Larva}

The larva is a typical, pale yellowish-white fruit fly maggot, cylindrical in shape, with inconspicuous head and 11 body segments which are not clearly separable into thoracic and abdominal regions.

\section{Segments}

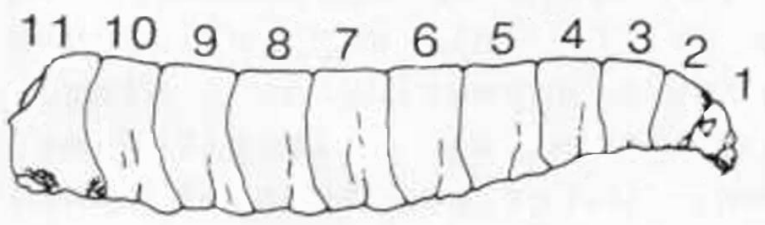

Figure 1. Third instar larva, lateral view. Credits: Division of Plant Industry

The head is a compound structure appearing as a single small segment with no definite head capsule. The oral cavity is composed of a longitudinal cavity which contains two black mouth hooks that move up and down. Outer portions of hooks protrude from preoral cavity, and bases articulate with pharyngeal skeleton. Shape of hooks and form of pharyngeal skeleton provide useful identification characters, as do buccal carinae. A. striata has eight to nine buccal carinae.

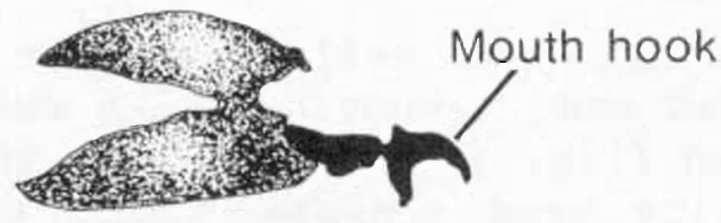

Figure 2. Pharyngeal skeleton and mouth hooks, lateral view. Credits: Division of Plant Industry

The two anterior spiracles, located laterally at base of first body segment behind head, are modified ends of tracheae divided into small tubules or digits. Anterior spiracles are small and asymmetrical in shape, anterior margin of each, in A. striata, bearing 13 to 17 tubules arranged in a transverse row with median indentation as seen in profile. Caudal segment possesses pair of posterior spiracles, each with three long spiracular openings called "slits". Length, width, and position of these are useful characters in

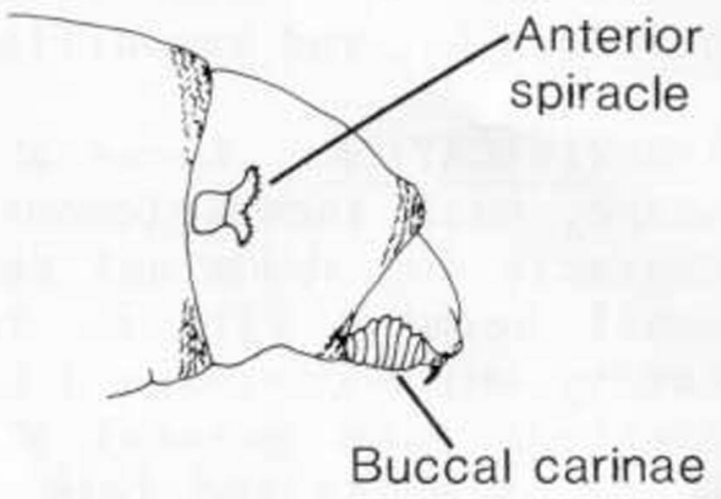

Figure 3. Head, lateral view, showing buccal carinae and anterior spiracle. Credits: Division of Plant Industry

separating species. Posterior spiracular entrances of A. striata about five times longer than wide; posterior spiracular hairs numerous and slender.
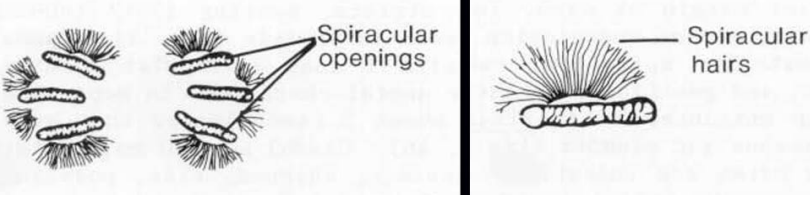

Figure 4. Posterior spiracles (left) and posterior spiracle with spiracular hairs above (right), of the guava fruit fly, Anastrepha striata Schiner. Credits: Division of Plant Industry

Caudal segment may contain tubercles or papillules which often are indistinct. Presence, absence, size, position, and number of these tubercles may be useful in identification of fruit fly larvae. $A$. striata has four small caudal papillules above and below posterior spiracles. Caudal papillules of $A$. striata below posterior spiracles usually minute or apparently absent or arranged in a transverse row, in contrast, for example, to those of the Mexican fruit fly, Anastrepha ludens (Loew), which are arranged in two rows, a lateral pair well ventrad of mesal pair.

Anal lobes of A. striata bifid. Full-grown larva to $10 \mathrm{~mm}$ in length and approximately $2 \mathrm{~mm}$ in diameter.

\section{Adult}

The adult fruit fly is rather small to medium sized; yellow brown, thorax patterned with black. The length of mesonotum is $2.45-3.57 \mathrm{~mm}$. Wings are 5.9-7.7 mm long, with yellow brown bands; costal 


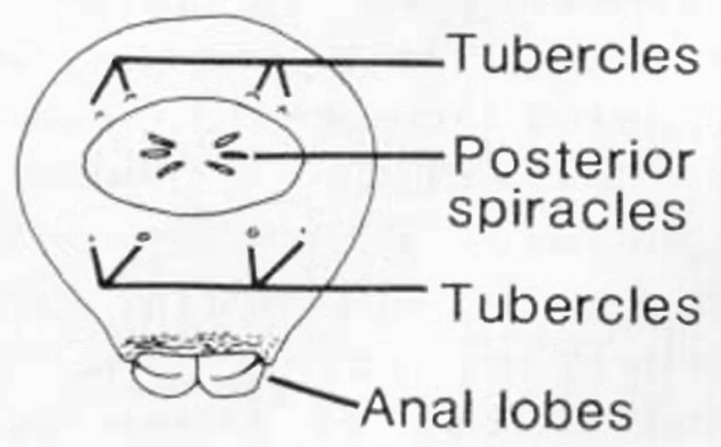

Figure 5. Posterior extremity of third instar larva. Credits: Division of Plant Industry

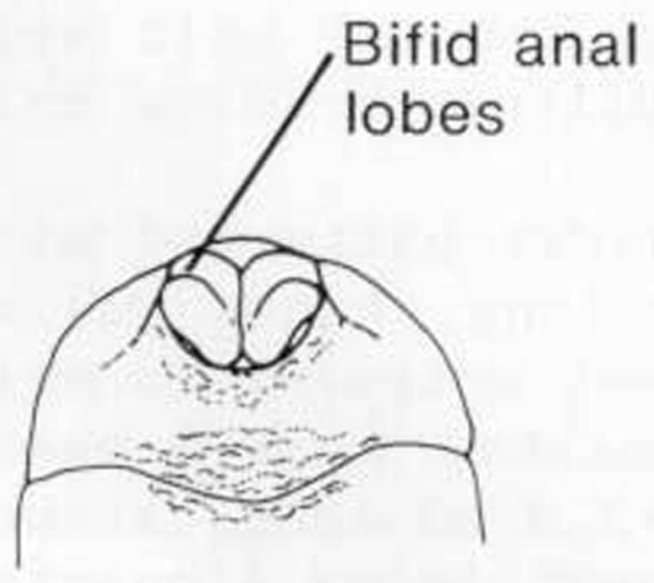

Figure 6. Posterior extremity, ventral view. Credits: Division of Plant Industry

and $\mathrm{S}$ bands touching on vein $\mathrm{R} 4+5$ and usually again just anterior to vein $\mathrm{R} 2=3$, leaving a small hyaline spot in cell R3; V band complete, separated from $\mathrm{S}$ band, outer arm narrow.

Female terminalia: ovipositor sheath $2.6-2.9 \mathrm{~mm}$ long, stout, tapering posteriorly, spiracles $1.05 \mathrm{~mm}$ from base. The rasper is well developed, hooks elongate, slender, in four or five rows. The ovipositor is 2.0-2.15 mm long, stout, tip broad and blunt without distinct serrations; and the shaft is slightly broadened at base.

Male terminalia: tergal ratio about 1.19 ; claspers about $0.44 \mathrm{~mm}$ long, flattened, posterior surface with a distinct carina from near base to apex of teeth; lateral margin beyond teeth convex, carinate; extreme apex narrow, abruptly turned posteriorly; teeth about at middle. The only species with thoracic pattern and wing pattern closely resembling this species is

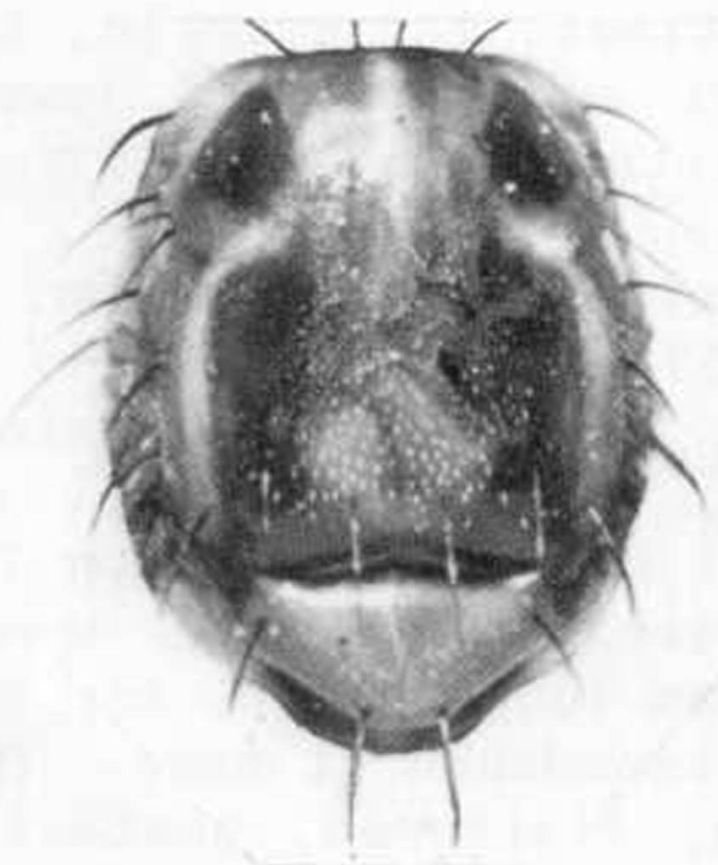

Figure 7. Thorax, dorsal view, of the guava fruit fly, Anastrepha striata Schiner. Credits: Division of Plant Industry

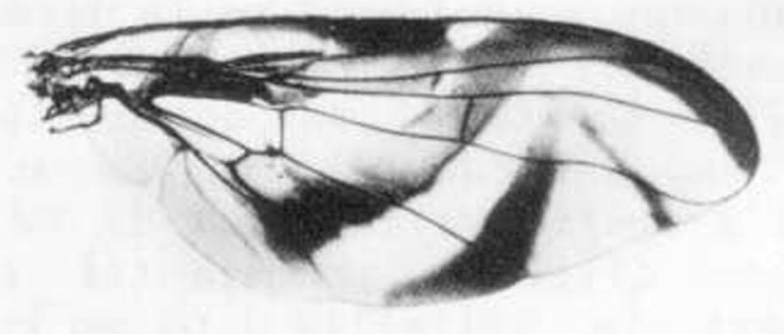

Figure 8. Wing of the guava fruit fly, Anastrepha striata Schiner. Credits: Division of Plant Industry

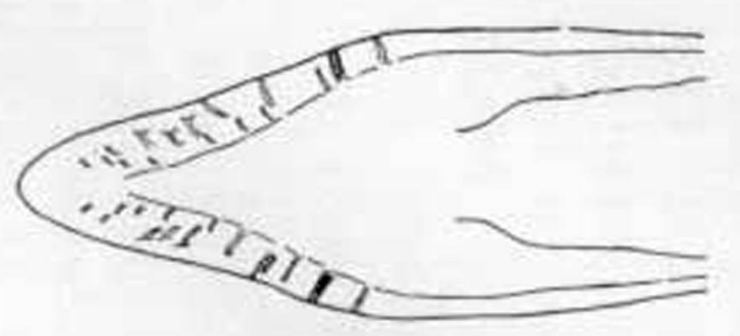

Figure 9. Ovipositor of adult female. Credits: Division of Plant Industry 


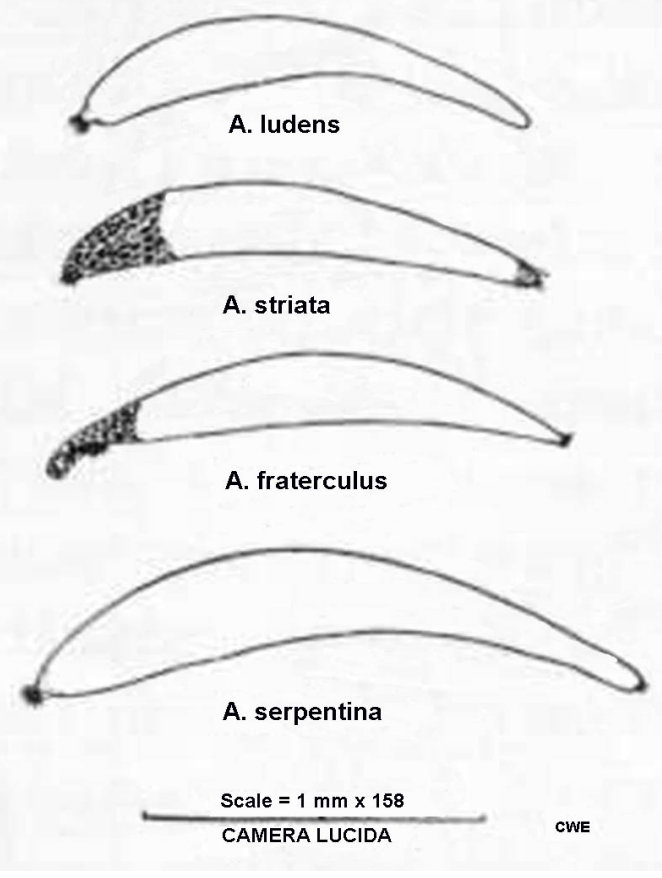

Figure 10. Egg of the guava fruit fly, Anastrepha striata Schiner, compared with other common Anastrepha species. Credits: Division of Plant Industry

Anastrepha bistrigata Bezzi. Lateral half of brown stripe on mesoscutum from transverse suture to scutellum denuded in A. striata; brown stripe wholly setose in A. bistrigata.

White and Elson-Harris (1994) state that $A$. striata is separated from the other species with a complete Anastrepha type wing pattern by the short (under $2.0 \mathrm{~mm}$ ) aculeus witha non-serrate apex and U-shaped pattern on the scutum.

Anastrepha striata is the only species of Anastrepha in which the mating behavior is known to include trophallaxis (passing of a substance from the male to the female via the mouthparts) (Norrbum 2001).

\section{Hosts}

Guava, Psidium guajava L., is the preferred food host. Others include spicewood, Psidium sartorianum; mango, Mangifera indica; Spondias sp., near hog plum or mombin, Spondias mombin; and seed pods of cassava, Manihot esculenta; avocado, Persea americana; black sapote, Diospyros digyna, green sapote, Pouteria viridis; Brazilian guava, Psidium guineense; cassava, Manihot escullenta; peach, Prunus persica; rose-apple, Syzgium jambos; star-apple, Chrysophyllum cainito; strawberry guava, Psidium littorale; sweet orange, Citrus sinensis; tropical almond, Terminalia catappa; and wild guava, Psidium friedrichsthalianum. This fruit fly has been reared in the laboratory from Surinam cherry or pitanga, Eugenia uniflora, and sapodilla, Manilkara zapota. (White and Elson-Harris 1994).

\section{Survey and Detection}

Larvae can be collected from infested fruit, but are very difficult to identify except when raised to adults. They tend to flex and jump up to $25 \mathrm{~mm}$ when mature. For larval preservation, kill in boiling water, place in $50 \%$ alcohol for 2 days, then to $75 \%$ isopropyl alcohol. Adults usually are collected by stickyboard and baited traps.

\section{Selected References}

Berg GH. 1979. Clave ilustrada de larvas de moscas de la fruta de la familia Tephritidae. Organismo Internacional Regional de Sanidad Agropecuaria (OIRSA), San Salvador, Republica de El Salvador. 36 p.

de Costa LA. 1934. Moscas de frutas do genero Anastrepha Schiner, 1868 (Diptera: Trypetidae). Memorias do Instituto Oswaldo Cruz 28: 487-575.

Norrbom AL. (31 October 2001). Anastrepha striata Schiner. The Diptera site. http://www.sel.barc.usda.gov/diptera/tephriti/ Anastrep/striata.htm (19 January 2002).

Pruitt JH. 1953. Identification of fruit fly larvae frequently intercepted at ports of entry of the United States. Unpublished M.S.thesis, University of Florida, Gainesville. 69 p.

Stone A. 1942. The fruitflies of the genus Anastrepha. U.S. Department of Agriculture Miscellaneous Publication No. 439, Washington, D.C. $112 \mathrm{p}$.

White IM, Elson-Harris MM. 1994. Fruit Flies of Economic Significance: Their Identification and Bionomics. CAB International. Oxon, UK. 601 p. 